\title{
Joseon Exorcist and the 'Uncanny Valley' of Korean Historical Dramas: On the Problems of 'Distorted' Representations of History in Korean Popular Culture Products
}

Ki, Kyoung-ryang*

\section{What was the issue with Joseon Exorcist?}

It was in March 2021 that SBS, one of the representative private TV broadcasting stations in South Korea, launched a new drama series Joseon Exorcist (Chosŏn kumasa). From the beginning, it was publicized as an ambitious, large-scale project, to be aired in sixteen episodes, with the production budget amounting to 32 billion won (approximately 28 million dollars). Considering that its genre identity was decidedly nonmainstream, its large production budget was considered unusual. We can speculate that SBS had been stimulated by the worldwide success of Netflix's Kingdom, a zombie horror TV series set in the $17^{\text {th }}$ century Chosŏn Korea following the Imjin Wars. Running for two seasons in 2019 and 2020, Kingdom has received a good deal of praise both inside and outside Korea for its fresh subject, innovative direction and captivating storyline. ${ }^{1}$

Initially, Joseon Exorcist seemed like a surefire hit. Its first episode

\footnotetext{
* Associate professor, The Catholic University of Korea

1 Two seasons of Kingdom, each season running six episodes, have been produced and the production budget for each episode is known to be around 2-3 billion won (approximately 1.7-2.5 million dollars).
} 
managed to generate 8.9 per-cent national ratings, with the by-moment rating chart showing the highest number at 10.7 per-cent, claiming the position of the most watched TV program for the day of its broadcast. However, almost as soon as the drama started serialization, an aggressive internet campaign insisting that the series was "distorting" (waegok) and "disparaging" (p'yŏmhwe) Korean history was launched in the internet. The drama's official webpage was inundated by the demand that the show be cancelled immediately. Aggressive criticisms and complaints poured into the SNS sites of the actors and staff members. Some viewers even hounded the sponsoring corporations behind the drama series with threats of boycotting the latter's products. These corporations were first to buckle, aghast at the explosive rage percolating in the cyberspace and rapidly discontinuing their financial support for the TV drama. SBS soon followed suit, cancelling the show only a week after launching it, despite the fact that ten out of sixteen promised episodes had already completed filming and were waiting to be broadcast. Needless to say, the remaining episodes were never filmed, and it is now extremely unlikely that the already-completed ten episodes would ever see the light of the day. This was an unprecedented event in the broadcasting history of Korean TV. What aspects of Joseon Exorcist provoked so much rage and hostility among a sizable number of South Korean viewers?

\section{Mixing Together Fantasy and "Real History": Different Interpretations of History and Failed Strategies to Win Over the Public.}

Joseon Exorcist is set in the early fifteenth century, immediately after foundation of the Chosŏn dynasty, specifically during the reign of King T'aejong (reign date 1400-1418). T'aejong is well known for his adroit but ruthless character, primarily based on the episodes of violent liquidation of his enemies in the process of founding the dynasty and subsequent succession struggle. Since Joseon Exorcist had been terminated with only 
two episodes run, it is not easy to determine how the series would have unfolded its historical narrative. Speculating from the publicized synopsis, poster design and character introductions, however, it appears that its plot was centered around T'aejong and his sons Prince Yangnyŏng and Prince Ch'ungnyŏng.

Prince Yangnyŏng, T'aejong's oldest, had originally been the designated crown prince but, due to his alleged decadent lifestyle and conflict with his father, the throne was passed on to his younger brother Ch'ungnyŏng, who eventually became King Sejong, touted as one of the greatest monarchs in Korean history. It is difficult to find in today's South Korea anyone who does not know this extremely well-known historical episode. Equally well-known is an apocryphal narrative that Yangnyŏng, in truth a brilliant and thoughtful person, deliberately misbehaved in such a way to hand the seat of the throne to his more deserving brother. There is little corroborating evidence to back up this popular story in the actual historical records, such as Chosón wangjo sillok. However, the unusual circumstances surrounding the succession of the king's title and struggles among the king and the two princes that ignored the cardinal principle of primogeniture, have attracted attention of the Korean producers of historical dramas over the years. It is not surprising, therefore, that Joseon Exorcist wanted to take advantage of this precedent of turning well-known historical personages into dramatic characters. Since the public were already familiar with these historical figures, the drama could save a lot of time and energy introducing and setting up these characters for the viewers. Unfortunately for Joseon Exorcist, this strategy backfired since the identity of this TV drama was a hybrid fantasy-historical drama.

According to the series director Sin Kyŏng-su, the main antagonist of the drama is Azazel, a wind demon originating from today's Middle East. In order to fight this demon, the drama introduces Father Nicholas and Father John, two European priest-exorcists dispatched by the Vatican. This element of European priests battling a Western demon in the context of Korean history probably struck many Korean viewers as unfamiliar and strange. We know that China had already established a relationship 
with Europe in thirteenth century, the Catholic authorities in Vatican and Kublai Khan of the Mongol Yuan dynasty exchanging envoys, for instance. However, in the context of South Korean history, Catholicism entered the public consciousness only in seventeenth and eighteenth centuries. A presence of European Catholic priests in the fifteenth century Chosŏn Korea thus generated a strong sense of cognitive dissonance that was difficult to swallow for many viewers (One could imagine an equivalent situation in which Buddhist monks appear to fight some Asian demons in a Western historical drama set in the medieval Europe). Perhaps the producers felt that a supernatural drama about exorcism must include Catholic priest-exorcists as a form of fidelity to the genre. Or perhaps they believed that having Western characters might add a sense of familiarity to the Western viewers, speculating that their series would be sold to the Euro-American market, following the precedent of Kingdom.

In the end, however, this strategy of mixing the setups and characters completely unmatched to the actual history with the well-known stories involving familiar historical figures such as T'aejong and Sejong ended up generating a subtle sense of unease and unfamiliarity among viewers. To understand how the viewers might have felt about this mixture, we may draw upon Mori Masahiro's theory of "uncanny valley," based on his exploration of the reasons for certain human-like forms of robots generating an increasing sense of disquiet and unease in the people observing or encountering them. This theory applies to not merely robots but also dolls modeled after human bodies or computer graphic images. An oftcited recent example of this "uncanny valley" phenomenon in a work of visual media is the Hollywood musical film Cats (2019), widely panned by critics and rejected by the public for what they considered off-kilter, vaguely obscene renditions of human actors into cat-like beings via special makeup effects and GGI effects.

Kim Ki-dŏk argues that this concept of uncanny valley can also be applied to the mixing of facts and fiction in a "faction" film. An imaginary excessively removed from factuality might appear to the public strange and bizarre, and moving away too much from the popular expectations 
regarding how historical "facts" should be "fictionalized" might result in a speedy rejection by the consumers. He goes further to claim that a work of fiction that ignores the system of historical recognition well entrenched in the public mind could potentially generate the viewer's hostility. ${ }^{2}$

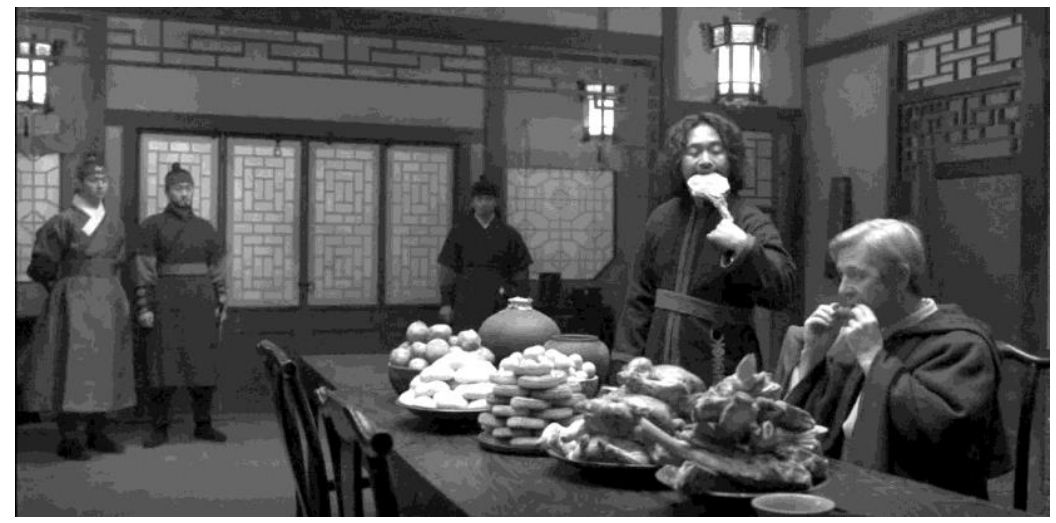

Indeed, Joseon Exorcist included a specific sequence that served to ignite displeasure among the viewing public. This is one during which Prince Ch'ungnyŏng treats Father John and his interpreter to a banquet dinner in a courtesan house located in Ǔiju, a border city proximate to the Ming dynasty. The banquet dinner was shown to include thousand-yearold eggs, mooncakes, dumplings and other foods not associated with the traditional Korean cuisine. Since the plot of the episode involved an imminent attack of courtesans possessed by evil spirits, the mis-en-scene of the sequence made use out of dark green and red lighting, rendering the visual scheme threatening and almost grotesque. Many Korean viewers were turned off by this sequence: in their minds, it seemed to turn the familiar vistas of the ordinary life in Chosŏn into something alien and unpleasant. Such negative feelings might be comparable to the sense of

2 Kim Ki-dŏk, "Paekshŏn yŏnghwa ŭi yuhaeng kwa taejungjŏk morip ŭi munje [The Popularity of Faction Films and the Problem of Viewer Immersion]," Yǒksa munhwa yŏngu, no. 34, 2009, pp. 458-474. 
alienation and displeasure many Koreans felt watching the depiction of "Korea" in a popular American TV series M.A.S.H. (1972-1983). The Korean viewers found that the producers (and many other filmmakers and TV producers subsequently) of the classic TV show tended to portray Korea as if it were Viet Nam, an Asian country foremost in the American public consciousness at the time. Korea, located in Northeast Asia, and Viet Nam, in Southeast Asia, had entirely different cultures and climates, the distinction that many Americans ignorant of the Asian histories and cultures could not make. The viewers of Joseon Exorcist were likely even more incensed that this type of "cavalier misrepresentation" of the Korean past had taken place in an ostensibly Korean production.

After the negative publicity about the series boiled over, its producers explained that such "foreignness" of the sequence was in part a result of deliberate design, taking into consideration that Ǔiju was a border city in constant contact with China. In fact, this explanation was a historically persuasive one. Given that historical records show Chosŏn's history of extensive economic and social communication with China through the city of Üiju, it is more than probable that there was a lodging in the city that predominantly catered to the Chinese clientele, thus providing Chinese food and other accoutrements favored by the latter. However, the incensed viewers refused to listen to this explanation and sought their own, namely that the TV drama and its "offensive" slant were all products of the infiltration of Chinese capital into the domain of the Korean popular culture.

\section{The Conflicts over Interpretations of History between South Korea and China}

This suspicion that Chinese capital was exerting a dark influence on the contents of the Korean popular culture had been brewing for some time before the explosive campaign against Joseon Exorcist materialized. For instance, tvN's contemporary dramas True Beauty and Vincenzo became 
objects of controversy due to their PPL (product placement) of Chinese food products, which were never even available for purchase in the Korean domestic market. ${ }^{3}$ The viewers had been complaining about the PPL for taking them out of their concentration on the drama itself, and the insertions of unfamiliar Chinese products into these dramas made them feel as if the Chinese capital was meddling with the South Korean media contents.

In truth, the negative emotions had been building between the two nations for a while. In 2016, when South Korea decided to establish the Terminal High Altitude Air Defense [THAAD] system following a strong demand from the US, China responded by issuing a comprehensive ban of Korean cultural contents, known as xianhanling (in Korean, hanhallyŏng 限韓令). This ban was extended not only to broadcasting and theatrical release of all Korea-produced contents in China and banning of advertisements featuring South Korean talents, but also to curtailing of certain import products from Korea and restriction of tourism from Korea. The South Korean economy suffered considerably due to this policy. AntiChinese sentiments have been on the rise among the Korean population ever since. According to one survey conducted in 2021, the "emotional temperature" Koreans feel toward China among foreign nations was the lowest among the countries surveyed at 26.4 degrees, not only lower than the US at 57.3, but also lower than Japan (28. 8) and North Korea (28.6). ${ }^{4}$

Prior to these diplomatic troubles, the so-called Northeast Project (Tongbei gongcheng, in Korean tongbuk kongjŏng 東北工程, short for Research Project on the History and Current State of the Northeast Borderlands), resulted in a conflict over historical interpretations between

3 "Hanguk dŭrama p'an e ttŏrŏjin 'chungguk kyŏnggyeryŏng," [The 'Chinese Warning' That Befell on the Korean Dramas], Sisa-in, no. 709, April 21, 2021.

4 The spectrum of "emotional temperature" ranges from zero, as the "coldest" and most negative all the way to a hundred, the "hottest" and most positive. "Chungguk ŭl sirŏhanŭn haeksim chiptan: Nugulkka?" [The Core Group Who Hate China: Who Are They?], Sisa-in, no. 717, June 17, 2021. 
China and South Korea. This project was originally slated as a five-year plan between 2003 and 2007 to study the past and present of the Northeastern regions of China. This project has angered many Koreans for its insistence in placing Koguryŏ (B. C. 1th century-- A. D. 668), one of the ancient Three Kingdoms whose territories had been spread over Manchuria and the northern part of the Korean peninsula, in the category of Chinese history. South Koreans had always regarded Koguryŏ as an essential component of their own history, and as such many among them were angered by this claim. Koguryŏ's alternate name, Koryŏ, was inherited by the medieval dynasty of the same name (918-1392) and henceforth has constituted an important element in constructing the Korean national identity of today. This conflict ended up exacerbating statism and nationalism in both sides. ${ }^{5}$

Thus, by the time Joseon Exorcist premiered, the image of China as an unreasonable and threatening presence that violates cultural and historical independence of South Korea by dint of its superpower status had been established among many Koreans. The latter today take strong pride in the global achievements of the Korean cultural contents, spearheaded by the winning of the Best Picture Oscar in 2020 by Bong Joon-ho's feature film Parasite, the worldwide popularity of K-pop groups such as BTS, and the great demands in Asian regions for the K-dramas and TV programs. These Koreans have come to see China as a freeloader seeking to infiltrate the Korean media contents and to take advantage of these achievements by means of its massive capital power.

During the controversy, South Korean cyberspace was a-buzz with the rumors that Joseon Exorcist was financed by the Chinese money, that its writer was a Chinese national and that his agency was likewise a Chinese company. None of these turned out to be true: no Chinese capital was involved in producing Joseon Exorcist, and its writer proved to be a Ko-

5 Im Ki-hwan, "Chungguk ŭi tongbuk kongjŏng yi namgin kŏt [What China's Northeast Project Has Left]," Yǒksa wa hyŏnsil, no. 62, p. 6. 
rean national. ${ }^{6}$ Many internet users were led around by these rumors, ultimately causing the collapse of an ambitious media content entirely produced by Koreans. They rationalized their negative campaign and its destructive outcome in the name of criticizing "historical distortion (yǒksa waegok)," allegedly perpetrated by the producers of Joseon Exorcist. Yet, the drama, while featuring actual historical figures from history, was essentially a fantasy, not aimed at a faithful recreation of the past. Few would have mistaken a TV show that all but begins with a supernatural horde of the "living dead" attacking people as an orthodox historical drama. All the same, the drama was severely criticized for "distorting" history. This is a readily available rhetoric in today's South Korea deployed in order to hold anyone ethically responsible, after all.

In today's South Korea, many, among them not just the viewing public but also historians, subscribe to the view that historical dramas should first and foremost strive to "accurately reconstruct the past." This attitude is ultimately too rigid for the good of our understanding of history. It is impossible anyway to perfectly reconstruct the past history in a popular cultural product. A compromise based on imagination is, to a certain degree, unavoidable.

The objectives behind telling stories based on history could be diverse: expression of historical consciousness, presentation of universal moral principles, emotionally moving the viewers, or simple entertainment and pleasure are all valid objectives. It might be problematic if a culture producer insists on branding his or her subjective imagination or prejudice regarding certain past facts as "history" without any objective reference or evidence. However, it could diminish the imaginative capacity of the culture producers if we brandish the ethical standard of "historical distortion" against every single historical drama, including those which have no quarrels with the existing history regarding facticity of its contents. We must accept that there are many different types of artistic works that serve a variety of purposes and acknowledge the essential creative freedom of 
the culture producers. Historians should move beyond the attitude that looks down on historical dramas, pointing out various "inaccuracies" in them. It would be much more productive for all concerned, if they could, by means of dependable and sincere commentaries and criticisms, take the encounters with these works as new opportunities to help the culture producers come up with alternative historical media contents and expand the perimeters of such endeavors. 